\title{
Distributed fibre-optic monitoring of an Osterberg-cell pile test in London
}

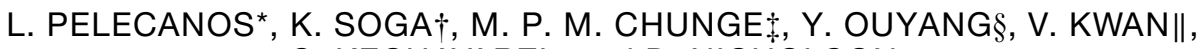 \\ C. KECHAVARZIף and D. NICHOLSON\|
}

\begin{abstract}
This paper presents a case study of an Osterberg-cell test of a pile located at the Isle of Dogs in London, which was heavily instrumented with distributed optical-fibre sensors, strain gauges, displacement transducers and extensometers. Special emphasis is given on the data from fibre optics, which offers an advantage due to their spatially continuous nature. The data show a clear development of shaft friction with the applied load and also some unexpected pile-soil slip within two of the soil layers, which is attributed to the development of a filter cake due to the long construction time. Relevant finite-element analyses are also conducted in an attempt to further understand the mechanisms of pile-soil slip, which highlight its importance in predicting the vertical displacements. Finally, some comments are included on the observed behaviour of the founding chalk layer.
\end{abstract}

KEYWORDS: field instrumentation; finite-element modelling; in situ testing

Published with permission by the ICE under the CC-BY licence http://creativecommons.org/licenses/by/4.0/

NOTATION

$A$ pile cross-sectional area

$D$ pile diameter

$d$ non-linear model degradation parameter

$E$ Young's modulus of the pile

$h$ non-linear model hardening parameter

$k_{\mathrm{m}}$ non-linear model maximum subgrade modulus parameter

$P$ applied load at the top of the pile

$r$ pile radius

$t$ shaft friction

$t_{\mathrm{m}}$ non-linear model maximum shaft friction parameter

$y$ depth

$y_{0}$ depth of absolute displacement measurement

$z$ vertical displacement

$z_{0}$ non-linear model initial-slip parameter

$\varepsilon \quad$ strain

\section{INTRODUCTION}

Pile load tests are vital for understanding the actual field behaviour of piles and for determining the relevant geotechnical parameters (Lehane \& Jardine, 1994; Seo et al., 2013; Bica et al., 2014). Appropriate instrumentation is crucial so that useful and reliable values for such aforementioned parameters are obtained for the designers (Coop \& Wroth, 1989; Randolph, 2003; McCabe \& Lehane, 2006). Although a wealth of pile top load-displacement curves is nowadays available (Jardine et al., 2013a, 2013b; Yang et al., 2014), the ability to acquire information along the pile depth opens

Manuscript received 6 June 2016; first decision 3 March 2017; accepted 16 March 2017.

Published online at www.geotechniqueletters.com on 18 April 2017.

*University of Bath, Bath, UK; Formerly University of Cambridge, Cambridge, UK.

†University of California, Berkeley, USA; Formerly University of Cambridge, Cambridge, UK.

tCOWI, London, UK.

§Cementation Skanska, Doncaster, UK.

IARUP, London, UK.

TCentre for Smart Infrastructure \& Construction (CSIC), Department of Engineering, University of Cambridge, Cambridge, UK. more opportunities for studying the real pile--soil interaction behaviour.

Traditional conventional instrumentation includes vibrating-wire strain gauges (VWSGs), electrical-resistance strain gauges, axial load cells and extensometers (Bond et al., 1991; Lehane et al., 1993; McNamara et al., 2014). Recent advances have made use of the interaction of laser pulses in fibre optics (FOs), through techniques such as fibre Bragg gratings (Kersey \& Morey, 1993; Lee et al., 2004; Liu \& Zhang, 2012; Doherty et al., 2015) and distributed Brillouin optical time-domain reflectometry (BOTDR) (Cheung et al., 2010; Mohamad et al., 2011; Hauswirth et al., 2014; Klar et al., 2014; Schwamb \& Soga, 2015; Kechavarzi et al., 2016; Acikgoz et al., 2017) to obtain larger datasets. The latter, due to their continuous nature, has a promising advantage over conventional, discrete instrumentation in providing detailed information about the pile performance (Klar et al., 2006; Ouyang et al., 2015).

This paper presents a case study of an Osterberg-cell (O-cell) pile test in London instrumented with distributed FO and other conventional instrumentation (VWSGs and extensometers). The monitored strain data from the three independent instrumentation techniques exhibit an excellent agreement. The strain, displacement and shaft friction (SF) test results are discussed and subsequently complemented by relevant finite-element (FE) analyses. It is shown that the spatially continuous field data from the FO measurements provided detailed information about the actual load transfer and revealed some unexpected pile-soil slip. Finally, the study highlights the importance of distributed monitoring information along the pile depth in accurately predicting its behaviour especially in terms of vertical displacements.

\section{O-CELL PILE TEST}

The instrumented pile is located at the Isle of Dogs in London. It is a reinforced-concrete bored test pile for a future high-rise tower. Although the pile was monitored during both curing of the concrete and the O-cell test, the analysis and discussion in this paper focuses on the latter only. 
Pile geometry and soil stratigraphy

The pile length is $51 \mathrm{~m}$ with a nominal diameter of $1.5 \mathrm{~m}$ and a reinforcement cage diameter of $1.35 \mathrm{~m}$. The cage was assembled in four sections and two O-cells were installed into the lowest cage section around $6 \mathrm{~m}$ above the pile toe. Due to unscheduled problems at the site, the construction of the pile was unusually long, spanning over more than $48 \mathrm{~h}$. The local soil stratigraphy (Fig. 1) consists of Made Ground overlying the Lambeth Group (sandy silty clay and silty clay), Thanet Sand and Chalk. During the load test, the O-cells expanded bidirectionally, applying a compressive load on the pile segments above and below reaching a maximum value of $30.87 \mathrm{MN}$ (Fig. 2).

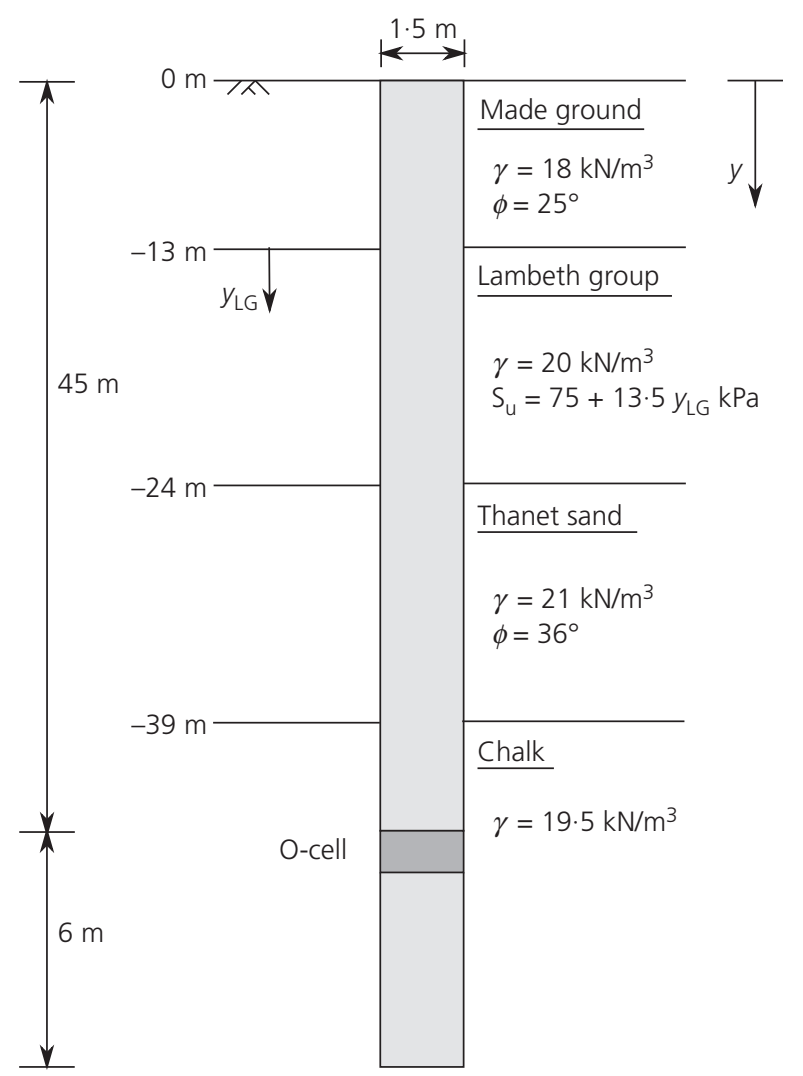

(a)

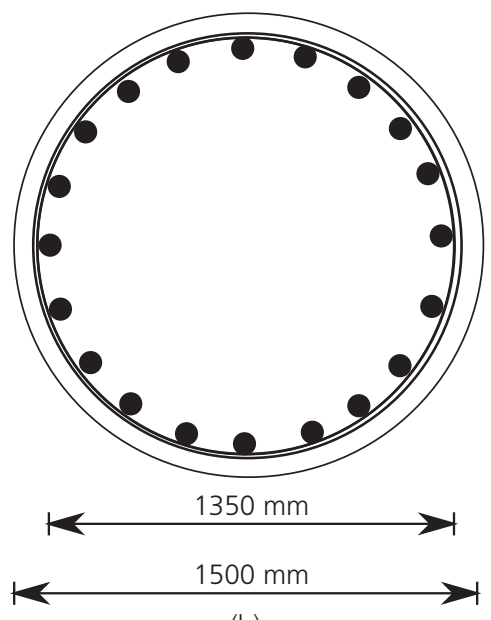

(b)

Fig. 1. Geometry of the test pile: (a) plan view and soil stratigraphy and (b) cross-section

\section{Instrumentation}

The pile was instrumented with distributed FO sensing cables, VWSGs, extensometers and linear vibrating-wire displacement transducers (LVWDT) (Fig. 3). The latter provide absolute displacement values. Two types of FO cables were installed: a reinforced Fujikura and an Excel Unitube measuring strain and temperature, respectively. They were attached to the reinforcement cage prior to concrete casting and they were split into two regiments based on their point of termination: above the O-cell and to the pile bottom. The temperature cables were attached loosely to the cage whereas the strain cables were pre-tensioned to about 1500-2000 $\mu \varepsilon$. In total, ten FO cables were installed, four strain and six temperature cables, in four bundles around the circumference and in two regimes along the length of the pile, as shown in Fig. 3. A Neubrex BOTDR analyser with a spatial resolution of $0.5 \mathrm{~m}$ was used during the measurement programme with a sampling interval of $0.05 \mathrm{~m}$ and typical noise of $\sim 30 \mu \varepsilon$. The BOTDR technology is based on the change of Brillouin frequency of the backscattered light shed through an optical fibre that is directly proportional to the applied mechanical strains and experienced temperature variations. Therefore, the backscattered light originates from scatters along the length of the fibre, becoming the actual sensor (Horiguchi et al., 1995; Soga, 2014; Soga et al., 2015).

\section{DATA ANALYSIS \\ Field data}

Figure 4 shows the monitored axial mechanical strain during the load test, which has been compensated for temperature changes (Soga, 2014; Soga et al., 2015). As expected, higher strains develop at close to the O-cell and their values reduce towards the top of the pile due to the development of SF. However, the strain profiles within the chalk layer seem to be rather constant implying a small SF contribution from the chalk layer.

Figure 5(a) compares data from the FO, VWSG and extensometer sensors; the strains from the extensometer data were calculated using the difference in displacements of two consecutive extensometer instruments divided by their distance. Generally, a very good agreement is obtained for the independent sensing systems. The waviness observed in the FO data is not instrument-related noise but it is the real strain state within the pile; Since all four strain cables in the

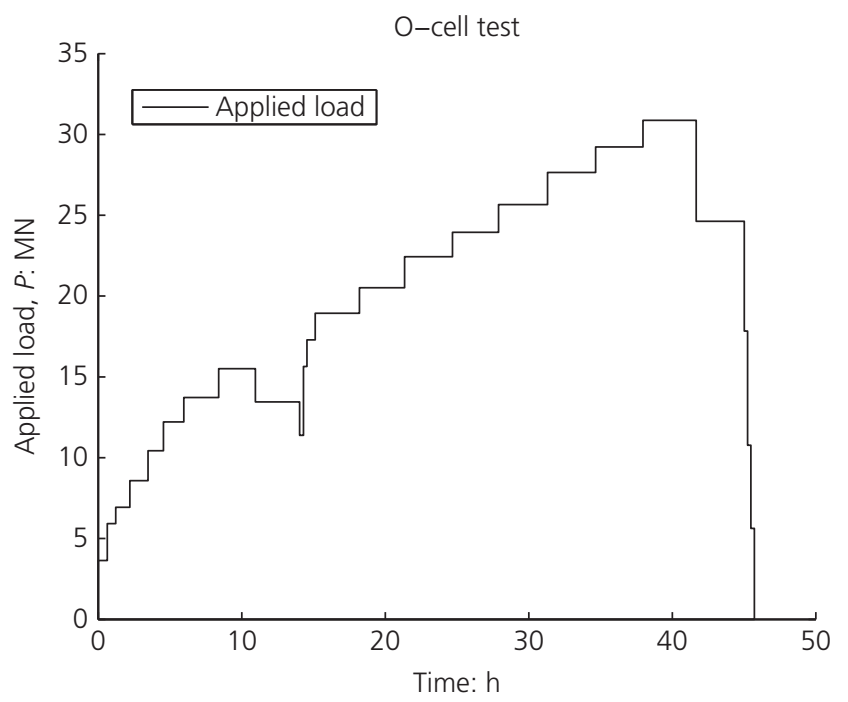

Fig. 2. Schedule of the O-cell test 

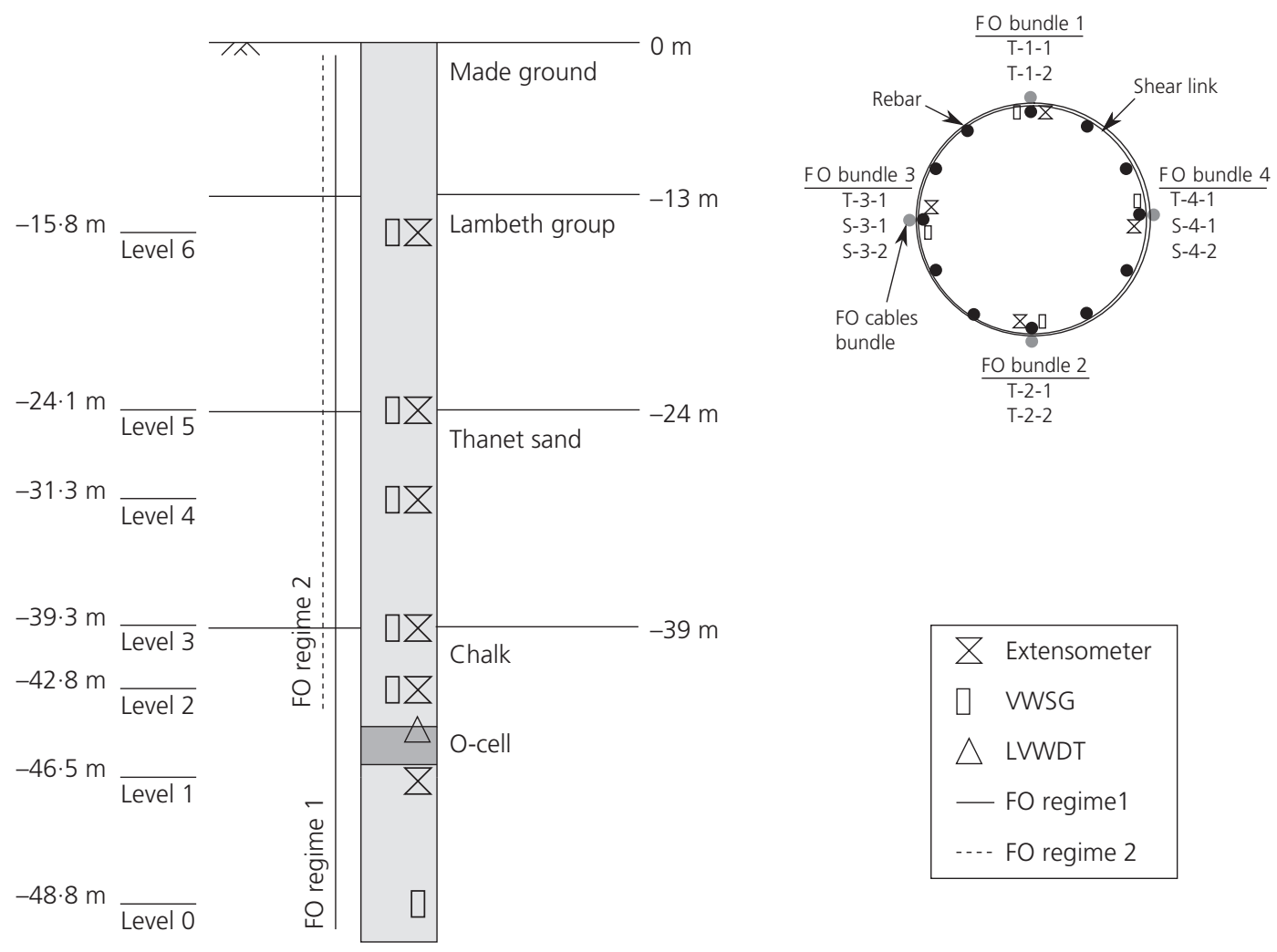

Fig. 3. Description of instrumentation

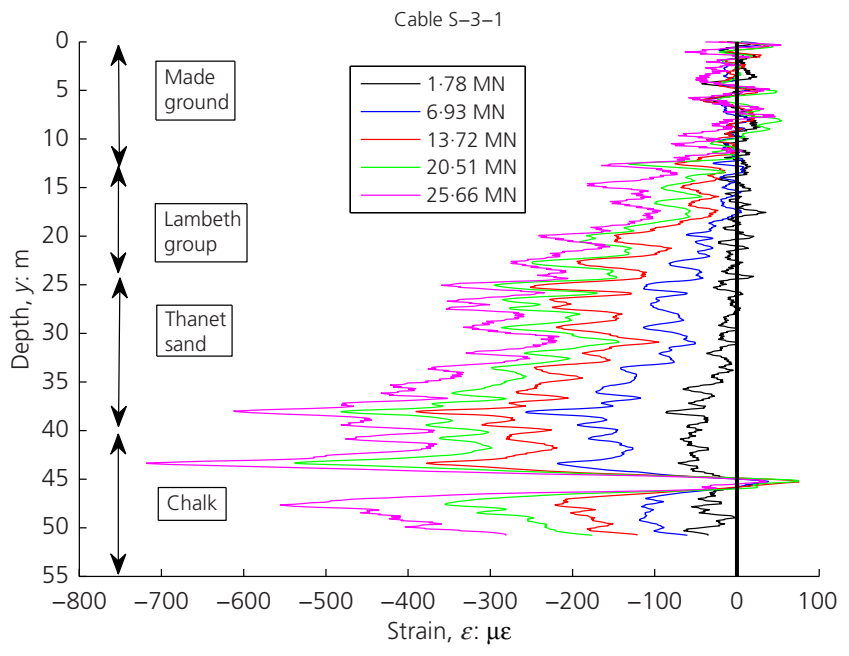

Fig. 4. Monitored axial strain developed in the pile for increasing O-cell loads

pile show consistent profiles of strain and very similar waviness (Fig. 5(b)), it is believed that this waviness is due to the irregular profile of the pile diameter (Fig. 6), along the depth which results in non-uniform axial rigidity, EA. Other possible reasons that might affect the waviness to a lesser extent are the periodic location of the circumferential steel reinforcement $(\sim 2 \mathrm{~m})$ and the staged tremie pipe concreting process. Similar waviness was observed in the strain profiles during concrete curing during which thermal effects may also have an effect.

The distributed nature of FO data allows for direct integration of the strains to obtain the absolute vertical displacements, $z$, of the pile when absolute movements $\left(z\left(y_{0}\right)\right)$ are measured (from the LVWDT), as given by equation (1) and illustrated in Fig. 7 (this refers to the pile above the O-cell). The local relative vertical displacements $z$ calculated were found to be in excellent agreement with those obtained from the extensometers at different elevations, as shown in Fig. 8

$$
z(y)=z\left(y_{0}\right)+\int_{y_{0}}^{y} \varepsilon_{\text {axial }} \mathrm{d} y
$$

Finally, differentiation of the strain profiles with depth allows for an estimation of SF, $t$. A value of axial rigidity $\mathrm{EA}=52200 \mathrm{MN}$ was adopted, assuming $E=30000 \mathrm{MPa}$ for concrete and uniform $A=\pi r^{2}(r=0.75 \mathrm{~m})$. Figure 9 shows the development of SF with $z$ at the four different soil layers, using first-order fitting polynomials to the strain profiles over each soil layer considered, as shown in Fig. 4.

There is some variability in the Made Ground layer (Fig. 9(a)) and SF reaches a maximum value of about $80 \mathrm{kPa}$ with an average of $20-60 \mathrm{kPa}$ for the four different cables. Presumably, some variability in the Made Ground is expected as this layer may not be homogeneous. Besides, this may suggest that the axial stiffness of the pile may not be uniform across the entire cross-sectional area, perhaps due to some construction imperfections (e.g. entrapped cavities from inadequate concrete compaction).

The Lambeth Group (Fig. 9(b)) shows consistent readings between the four FO cables and SF reaches a clear plateau at about $170 \mathrm{kPa}$. This value is similar to $\mathrm{SF}$ observed in previous pile tests at Canary Wharf (Chapman et al., 1999; Nicholson et al., 2002) that yielded values of around $162-185 \mathrm{kPa}$. An interesting observation is the initial minor SF development. This might suggest some initial pile-soil slip before the whole frictional SF develops, which is different from the high initial shaft stiffness considered in 

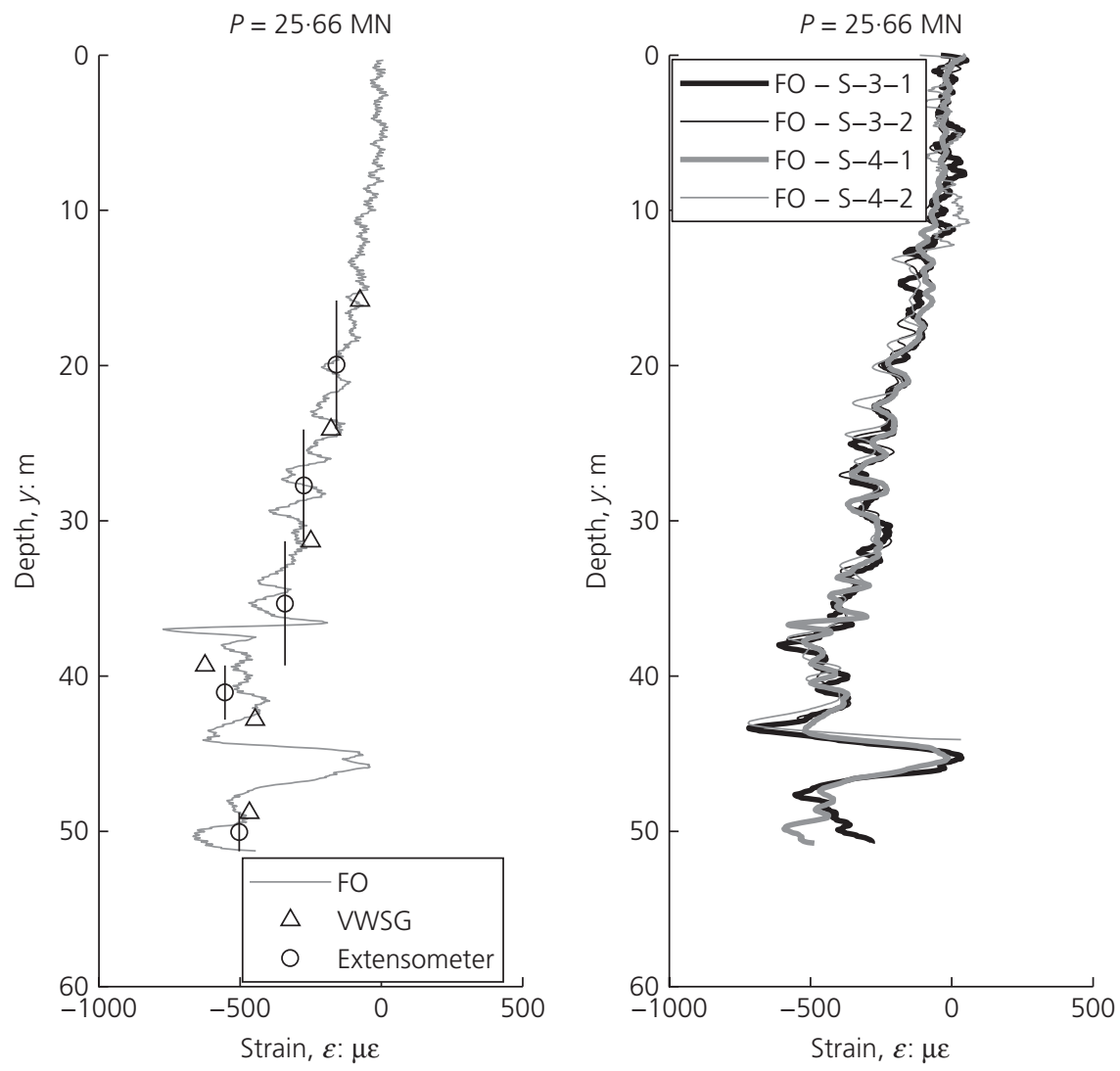

Fig. 5. Comparison of the fibre-optic cable readings

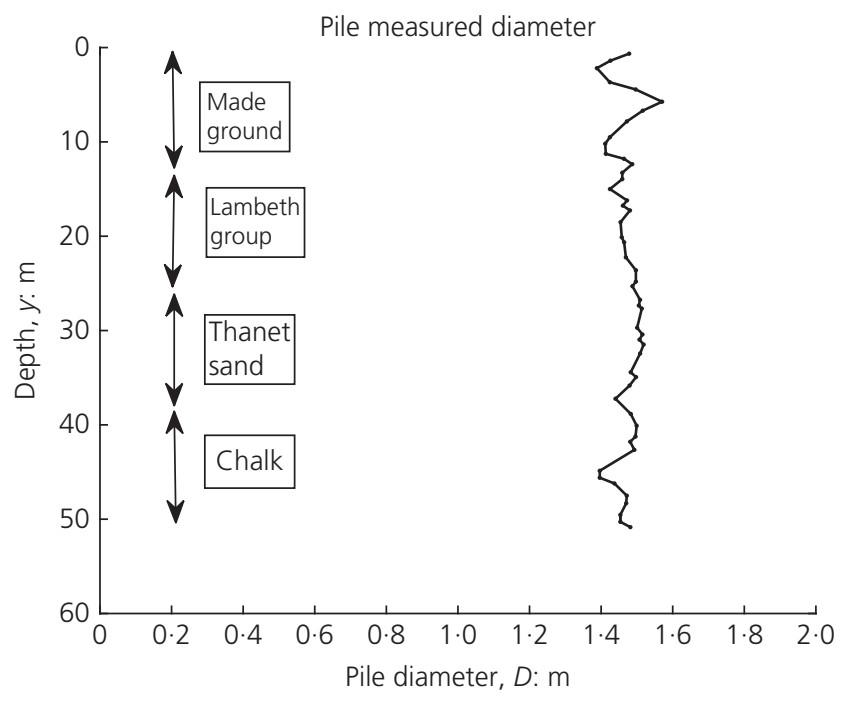

Fig. 6. Measured pile true diameter from in-situ sonic tests

the conventional pile design. The implication of this is discussed in the following section.

Thanet Sand (Fig. 9(c)) exhibits great consistency among different cables and SF increases reaching about $160 \mathrm{kPa}$ without any plateau. Different from the Lambeth Group layer, there is high initial SF 'stiffness'. The observed SF values in the Thanet Sand seem to be smaller than those observed at previous pile tests at Canary Wharf (Chapman et al., 1999; Nicholson et al., 2002) and the suggested values of $170-614 \mathrm{kPa}$.

The bottom chalk layer shows significant variability between the four different cables as shown in Fig. 9(d). Despite the observed variability, all cables show some small

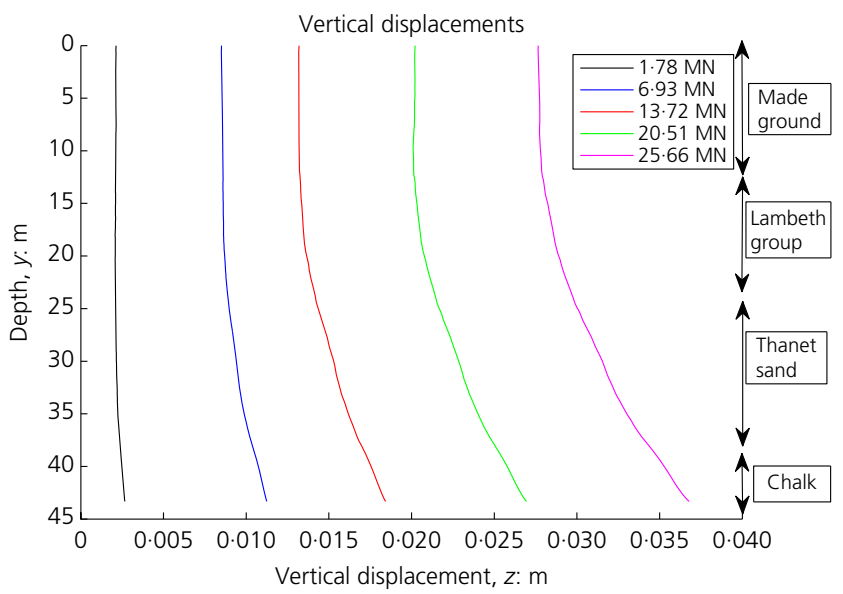

Fig. 7. Calculated vertical displacement of the pile during the load test

initial values (for $z \simeq 0.02 \mathrm{~m}$ ) and subsequent development of $\mathrm{SF}$ of about $300 \mathrm{kPa}$. This pile-soil slip-like trend is similar in complexity to what was observed in the Lambeth Group layer. However, some unexpected negative values of SF can be observed, especially for cables S-3-2 and S-4-2, which are perhaps due to the approach followed to derive the SF using fitted polynomials over a relatively short length compared with the waviness. It is recognised that at this point solid conclusions cannot be made regarding this issue in the Chalk and it clearly needs further investigation. Nevertheless, in general (apart from Made Ground and Chalk) all four cables seem to show consistent development of SF with $z$. The ultimate value of SF observed here is generally smaller than what is reported in the relevant CIRIA guide (CIRIA, 2002). 

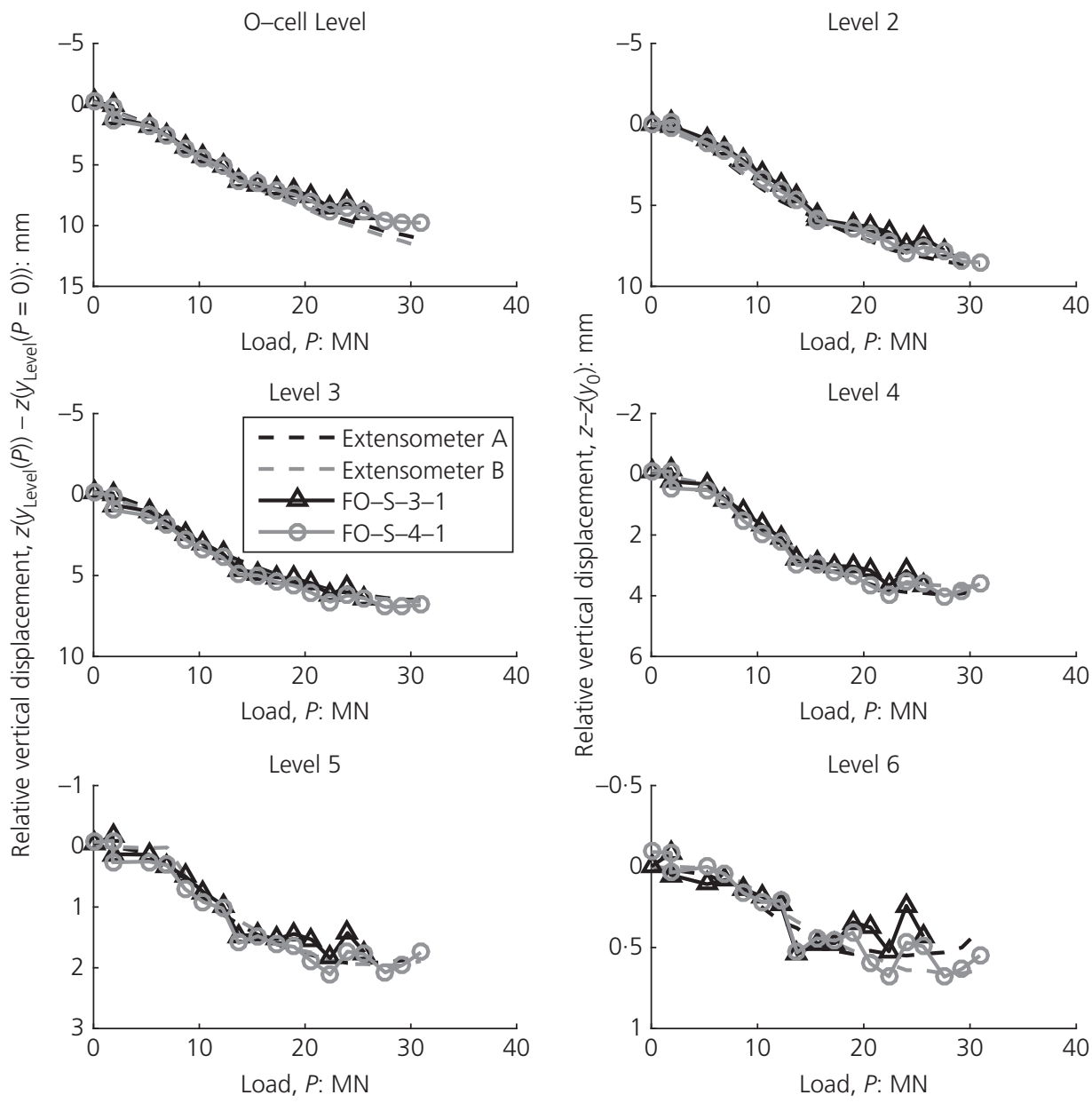

Fig. 8. Development of relative vertical displacements at different elevations along the pile depth (levels are presented in Fig. 3)
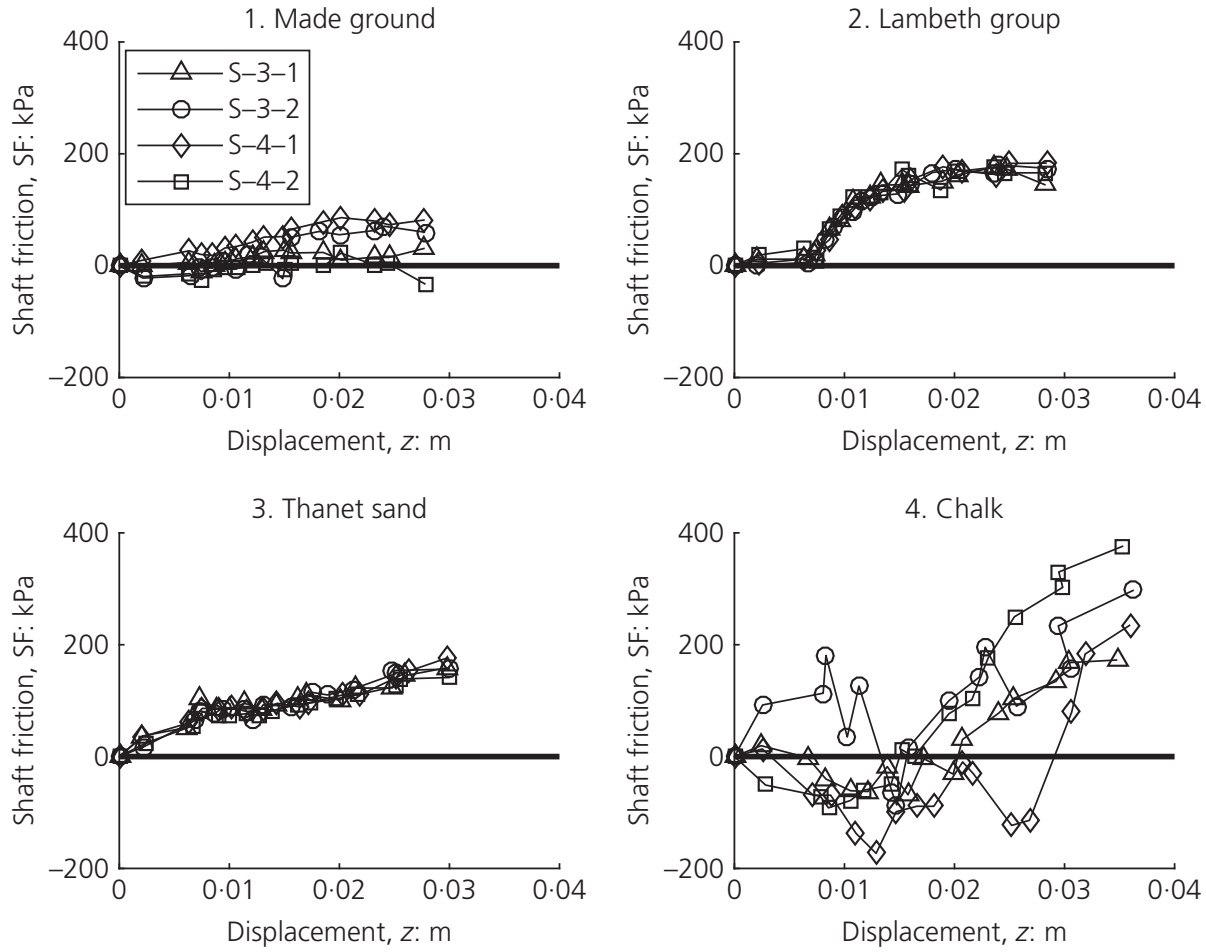

Fig. 9. Development of SF at different depths (soil layers) along the pile 
It is believed that the observed initial pile-soil slip is real and it is attributed to the development of a soft filter cake region in the chalk layer and possibly in the Lambeth Group, perhaps due to their permeability. This might be due to the long pile construction process. Usual pile construction practice involves dry excavation and subsequent stabilisation with bentonite slurry, followed by concreting in less than a work shift. This practice should not allow time for filter cake formation. However, the long construction time in this case allowed the penetration of bentonite into the surrounding soil, especially in the chalk layer and therefore possibly resulted in the development of a soft filter cake (Lam et al., 2010, 2013; Beadman et al., 2012; Lam \& Jefferis, 2016). Consequently, the observed initial slip and small values of ultimate SF observed in the Lambeth Group and chalk layers along with the slow mobilisation of displacements (Fig. 7) is potentially attributed to the existence of such a soft pile-soil interface. For small loads (and hence pile displacements), the soft thin filter cake layer adjacent to the pile provides small resistance, whereas for larger loads (and displacements) more stiffer soil beyond the filter cake is engaged and therefore provides larger resistance and SF. The other layers (Made Ground and Thanet Sand) seem to be less sensitive to filter cake formation. Further investigation is needed.

Moreover, estimations of the pile diameter profile were obtained by in-situ sonic caliper tests which showed some variability in the pile diameter with depth (Fig. 6). These tests suggested an undulating pile shaft diameter that resulted in ribbing in the pile. Such a rough pile-soil interface may have potentially resulted in an increase in shaft resistance due to local bearing capacity shearing actions between successive peaks in the pile diameter.

\section{Numerical FE analysis}

To get a better understanding of the mechanisms involved, a simple one-dimensional non-linear FE load-transfer analysis (Fig. 10) was conducted. The pile above the O-cell was modelled, and therefore a $45 \mathrm{~m}$ pile loaded from the bottom was considered with an element size of $0 \cdot 1 \mathrm{~m}$. Due to the observed pile-soil slip in the Lambeth Group and chalk layers, two load-transfer curves were adopted: a conventional hyperbolic (MODEL 1) (equation (2), with $z_{0}=0$ ) and an extended hyperbolic (MODEL 2) (equation (2) with $z_{0} \neq 0$ ), which allows for an initial slip (for $z_{0}>0$ )

$$
\begin{aligned}
t= & \frac{k_{\mathrm{m}} z_{0}}{\left[1+\left(k_{\mathrm{m}} z_{0} / t_{\mathrm{m}}\right)^{\mathrm{hd}}\right] 1 / \mathrm{d}} \\
& +\frac{k_{\mathrm{m}}\left(z-z_{0}\right)}{\left[1+\left(k_{\mathrm{m}}\left|z-z_{0}\right| / t_{\mathrm{m}}\right)^{\mathrm{hd}}\right]^{1 / d}}
\end{aligned}
$$

where $z_{0}$ is related to the initial slip; $k_{\mathrm{m}}, t_{\mathrm{m}}, d$ and $h$ are model parameters related to maximum SF (for the conventional

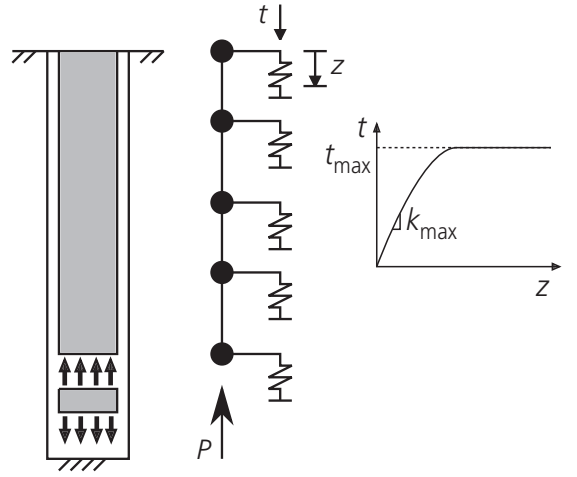

(a)

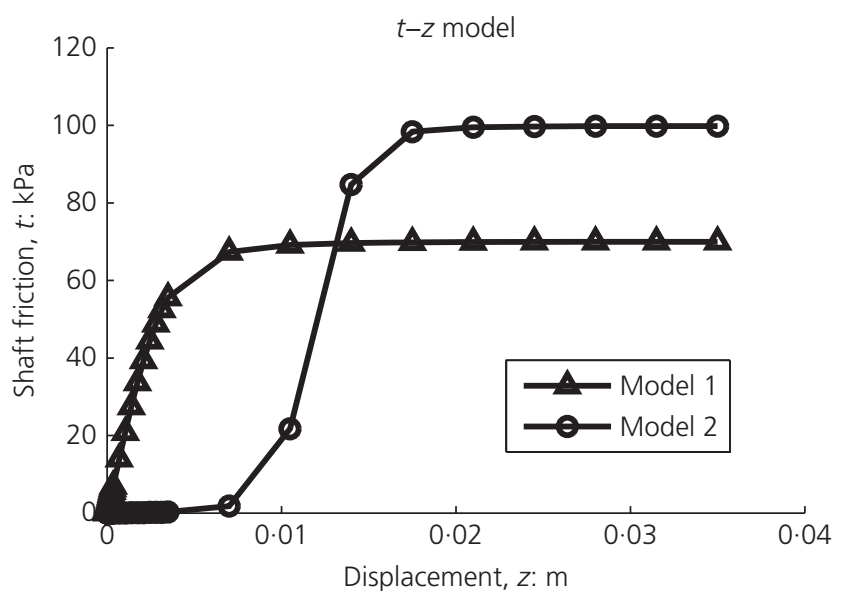

(b)

Fig. 10. Numerical load-transfer model: (a) problem and (b) load-transfer curve models

hyperbolic model MODEL 1 only, i.e. $z_{0}=0$ ), maximum soil stiffness (at $z=z_{0}$ ), hardening and degradation, respectively.

The load-transfer curves were calibrated (Table 1) based on the observed SF development curves (Fig. 11). Here, one set of curves (cable S-3-1) is used and it is shown that MODEL 2 follows the observed data very well, whereas MODEL 1 was calibrated based on a best fit for the whole range of experienced $z$. Therefore, for the best compromise, for Made Ground and Lambeth Group, MODEL 1 overestimates the stiffness for smaller loads and underestimates for larger loads.

Figure 12 shows the monitored (cable S-3-1) and calculated axial strains for four representative load cases. It is shown that, especially for smaller loads, MODEL 1 results in higher strains, whereas MODEL 2 exhibits a better agreement. This is due to the known overestimation of stiffness of MODEL 1 in the upper two soil layers and its inability to model the initial pile-soil slip-like behaviour.

\begin{tabular}{|c|c|c|c|c|c|c|}
\hline Model & Layer & $t_{\mathrm{m}}: \mathrm{kPa}$ & $k_{\mathrm{m}}: \mathrm{kN} / \mathrm{m}^{3}$ & $d$ : dimensionless & $h:$ dimensionless & $z_{0}: \mathrm{m}$ \\
\hline $\begin{array}{l}1 \\
1 \\
1 \\
1 \\
2 \\
2 \\
2 \\
2 \\
2\end{array}$ & $\begin{array}{l}\text { 1. Made Ground } \\
\text { 2. Lambeth Group } \\
\text { 3. Thanet Sand } \\
\text { 4. Chalk } \\
\text { 1. Made Ground } \\
\text { 2. Lambeth Group } \\
\text { 3. Thanet Sand } \\
\text { 4. Chalk }\end{array}$ & $\begin{array}{r}15 \\
150 \\
212 \\
85 \\
10 \\
75 \\
212 \\
85\end{array}$ & $\begin{array}{r}4244 \\
10610 \\
10610 \\
2122 \\
4244 \\
42440 \\
10610 \\
21220\end{array}$ & $\begin{array}{l}3 \\
3 \\
1 \\
3 \\
3 \\
3 \\
1 \\
3\end{array}$ & $\begin{array}{l}1 \\
1 \\
0 \cdot 8 \\
1 \\
1 \\
1 \\
0 \cdot 8 \\
1\end{array}$ & $\begin{array}{l}0 \\
0 \\
0 \\
0 \\
0 \cdot 012 \\
0 \cdot 01 \\
0 \\
0 \cdot 025\end{array}$ \\
\hline
\end{tabular}

Table 1. Calibration parameters of the load-transfer model 

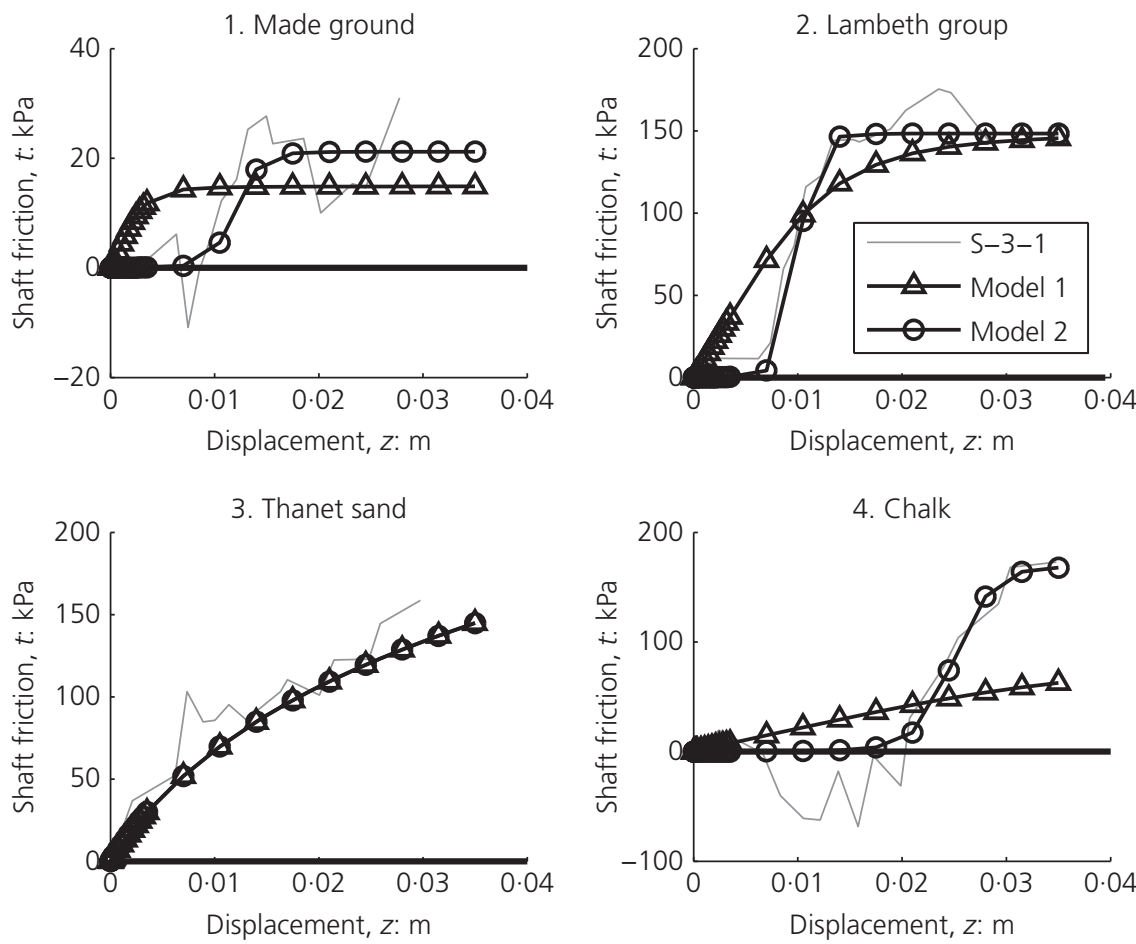

Fig. 11. Calibration of load-transfer curves
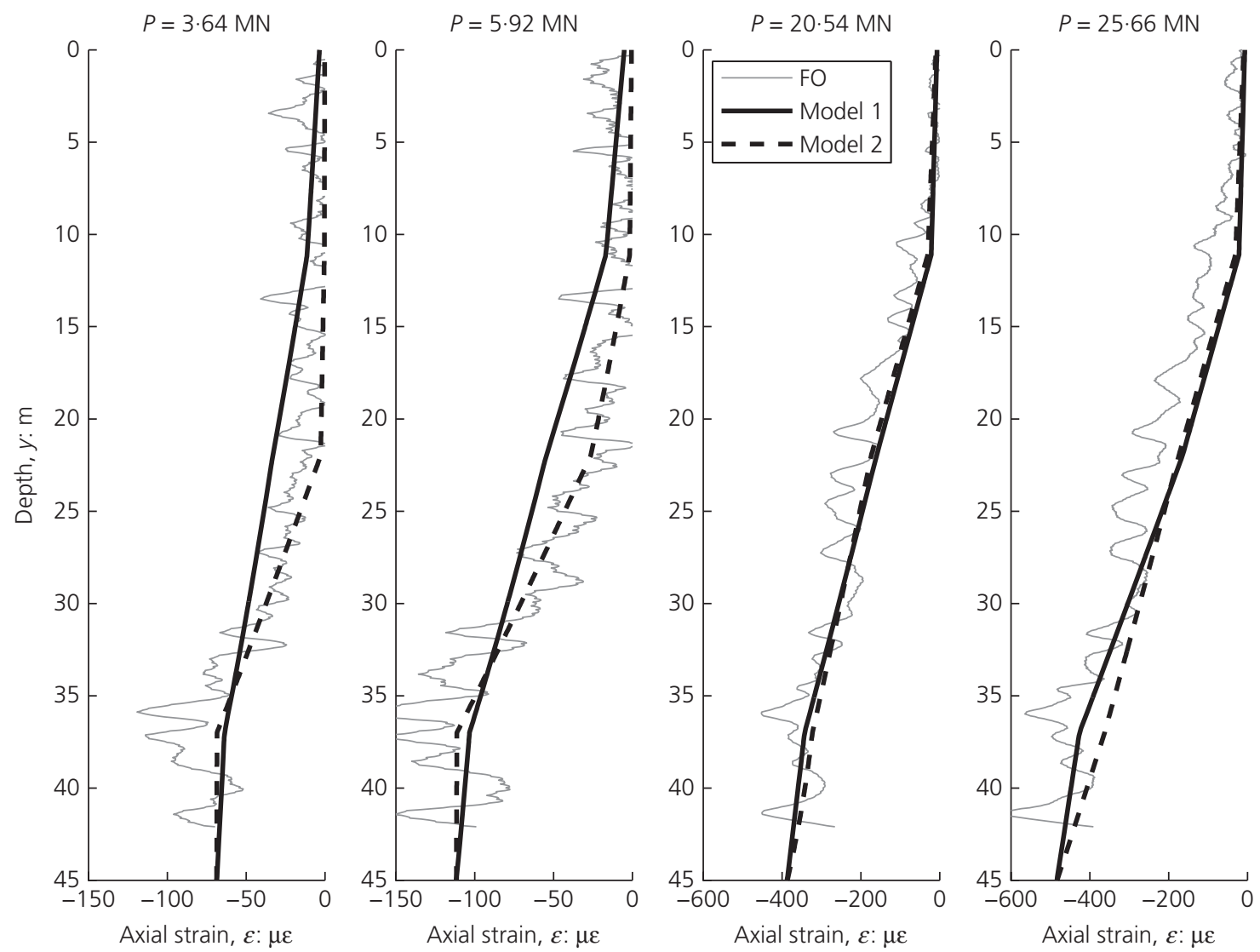

Fig. 12. Comparison of axial pile strains from field data and FE analysis

Figure 13 shows profiles of $z$ and illustrates that MODEL 1 underpredicts $z$ for smaller loads, while it overpredicts for larger loads. This is not surprising, as the standard hyperbolic curve equation was not able to accommodate the initial pile-soil slip-like behaviour observed in the Lambeth Group layer and was calibrated based on a compromise of best fit. In contrast, the modified curve of MODEL 2 to accommodate the initial slip was able to predict accurately the observed $z$. 

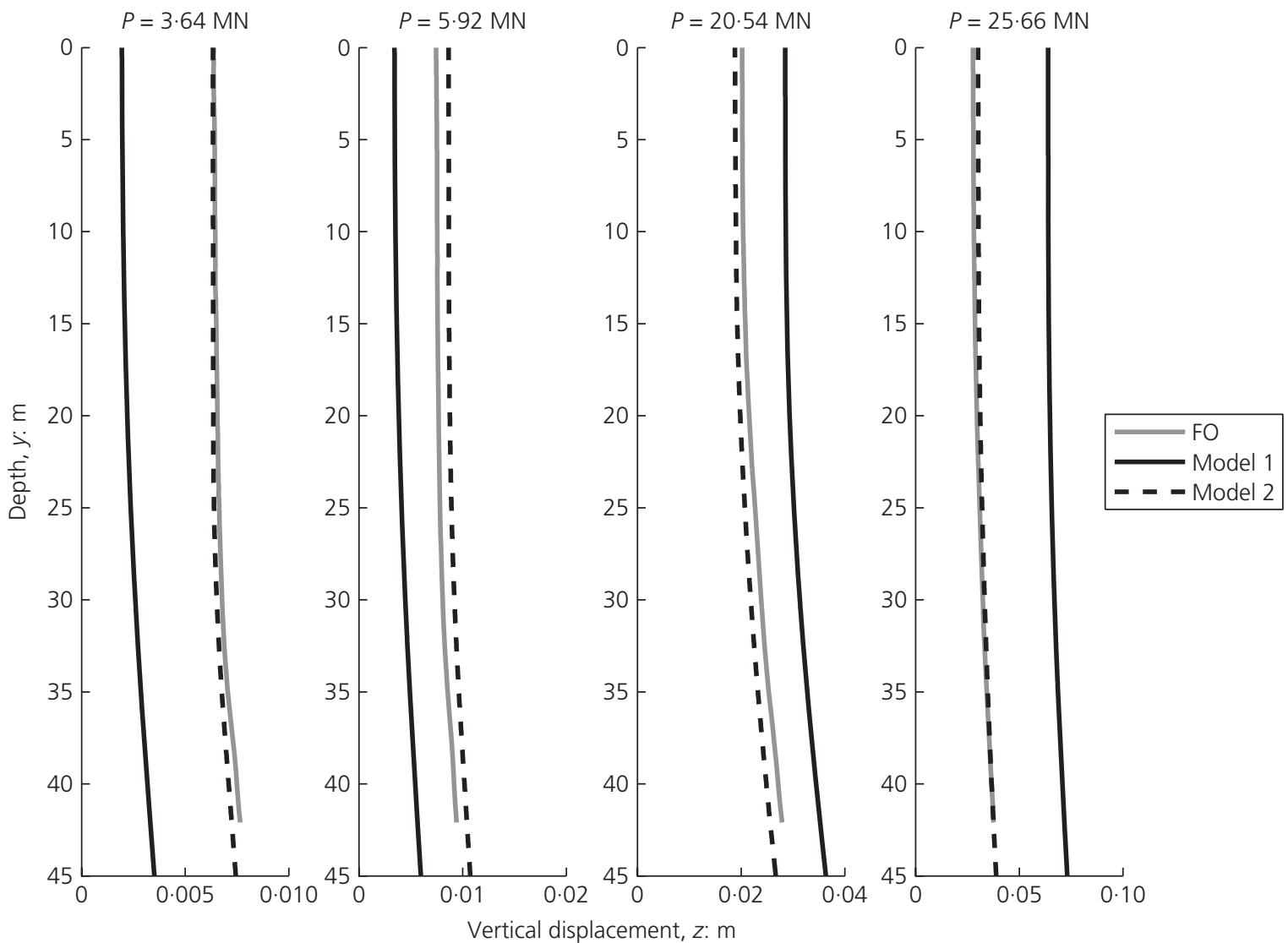

Fig. 13. Comparison of vertical pile displacements from field data and FE analysis

\section{CONCLUSIONS}

This paper presents a case study of the application of distributed FO sensing technology to the monitoring of pile load tests through the analysis of a recent test in London. The monitoring data of a biaxial O-cell test of a $51 \mathrm{~m}$ long pile, bored in a layered soil in the Isle of Dogs in London is analysed and compared with data from other independent instrumentation (VWSGs and extensometers) and the results of two simple FE numerical models. The main findings of this study are the following.

- The continuous nature of the monitored field data provides valuable detailed information on the axial strains along the pile depth including areas of localised strains.

- The distributed strain sensing data compare very well with other conventional instrumentation, such as discrete strain gauges and extensometers and they show consistency between different cables on the same pile. The irregular pile cross-sectional area, which results in non-uniform pile axial rigidity, EA, appears to be the primary cause for the observed waviness of the continuous FO strain data. Such a postulation is supported by the available in-situ sonic caliper tests that suggested a ribbed pile profile.

- The availability of continuous strain profiles can provide information on the vertical displacements and SF of the pile through direct numerical integration and differentiation, respectively. These can then be used to derive relevant load-transfer curves.

- The Lambeth Group and chalk layers exhibited some initial pile-soil slip-like behaviour before the development of the usual SF curve. Subsequent relevant numerical analyses were able to confirm that the modelling of the slip was necessary to match the FE simulation results with the field data. It is suspected that the long construction process of this pile and the extended time that the bentonite slurry was present in the borehole must have potentially resulted in the development of a soft filter cake at the pile-soil interface. As a consequence, these layers have exhibited an initial soft behaviour and then take-up of the expected load.

- The observed variable behaviour of the pile within the chalk layer was not very clear. The four cables showed some different strain development and the pile-shaft behaviour in the chalk layer clearly needs further investigation.

\section{ACKNOWLEDGEMENTS}

This research was conducted within the Centre for Smart Infrastructure and Construction (CSIC) at the Department of Engineering, University of Cambridge. It was funded by EPSRC and Innovate UK and their financial assistance is acknowledged. The authors also acknowledge the assistance of the CSIC group (Professor Lord Robert J. Mair, Dr Mohammed Elshafie, Dr Jennifer Schooling, Peter Knott and Jason Shardelow) and the industry partners ARUP and Canary Wharf Group plc. Finally, the authors acknowledge the critical feedback of the two anonymous reviewers, which helped to improve the presentation of the paper.

\section{REFERENCES}

Acikgoz, M. S., Pelecanos, L., Giardina, G., Aitken, J. \& Soga, K. (2017). Distributed sensing of a masonry vault during nearby piling. Struct. Control Health Monit. 24, No. 3, e1872.

Beadman, D., Pennington, M. \& Sharratt, M. (2012). Pile test at the Shard London Bridge. Ground Engng 45, No. 1, 24-29. 
Bica, A. V. D., Prezzi, M., Seo, H., Salgado, R. \& Kim, D. (2014). Instrumentation and axial load testing of displacement piles. Proc. Instn Civil Engrs - Geotech. Engng 167, No. 3, 238-252, http://dx.doi.org/10.1680/geng.12.00080.

Bond, A. J., Jardine, R. J. \& Dalton, J. C. P. (1991). The design and performance of the Imperial College instrumented pile. Geotech. Test. J. 14, No. 4, 413-424.

Chapman, T. J. P., Connolly, M., Nicholson, D. P., Raison, C. A. \& Yeow, H. C. (1999). Advances in understanding of base grouted pile performance in very dense sand. Tunn. Constr. Piling $\mathbf{9 9}$ $57-69$

Cheung, L., Soga, K., Bennett, P. J., Kobayashi, Y., Amatya, B. \& Wright, P. (2010). Optical fibre strain measurement for tunnel lining monitoring. Proc. Instn Civil Engrs - Geotech. Engng 163 No. 3, 119-130, http://dx.doi.org/10.1680/geng.2010.163.3.119.

CIRIA (2002). C574 - Engineering in chalk. London, UK: CIRIA.

Coop, M. R. \& Wroth, C. P. (1989). Field studies of an instrumented model pile in clay. Géotechnique 39, No. 4, 679-696, http:// dx.doi.org/10.1680/geot.1989.39.4.679.

Doherty, P., Igoe, D., Murphy, G., Gavin, K., Preston, J., McAvoy, C., Byrne, B. W., McAdam, R., Burd, H. J., Houlsby, G. T., Martin, C. M., Zdravkovic, L. T., Taborda, D. M. G., Potts, D. M., Jardine, R. J., Sideri, M., Schroeder, F. C., Muir Wood, A., Kallehave, D. \& Skov Gretlund, J. (2015). Field validation of fibre Bragg grating sensors for measuring strain on driven steel piles. Géotech. Lett. 5, No. 2, 74-79, https://doi.org/10.1680/geolett.14.00120.

Hauswirth, D., Puzrin, A. M., Carrera, A., Standing, J. R. \& Wan, M. S. P. (2014). Use of fibre-optic sensors for simple assessment of ground surface displacements during tunnelling. Géotechnique 64, No. 10, 837-842, http://dx.doi.org/10.1680/ geot.14.T.009.

Horiguchi, T., Shimizu, K., Kurashima, T., Tateda, M. \& Koyamada, Y. (1995). Development of a distributed sensing technique using Brillouin scattering. J. Lightwave Technol. 13, No. 7, 1296-1302.

Jardine, R. J., Zhu, B. T. \& Foray, Y. Z. X. (2013a). Interpretation of stress measurements made around closed-ended displacement piles in sand. Géotechnique 63, No. 8, 613-627, http://dx.doi.org/ 10.1680/geot.9.P.138.

Jardine, R. J., Zhu, B. T., Foray, P. \& Yang, Z. X. (2013b). Measurement of stresses around closed-ended displacement piles in sand. Géotechnique 63, No. 1, 1-17, http://dx.doi.org/10.1680/ geot.9.P.137.

Kechavarzi, C., Soga, K., de Battista, N., Pelecanos, L., Elshafie, M. Z. E. B. \& Mair, R. J. (2016). Distributed fibre optic strain sensing for monitoring civil infrastructure. London, UK: Thomas Telford.

Kersey, A. D. \& Morey, W. W. (1993). Multiplexed Bragg grating fibre-laser strain-sensor system with mode-locked interrogation. Electron. Lett. 29, No. 1, 112-114.

Klar, A., Bennett, P. J., Soga, K., Mair, R. J., Tester, P., Fernie, R., St John, H. D. \& Torp-Peterson, G. (2006). Distributed strain measurement for pile foundations. Proc. Instn Civil Engrs Geotech. Engng 159, No. 3, 135-144, http://dx.doi.org/10.1680/ geng.2006.159.3.135

Klar, A., Dromy, I. \& Linker, R. (2014). Monitoring tunneling induced ground displacements using distributed fiber-optic sensing. Tunnel. Underground Space Technol. 40, 141-150.

Lam, C. \& Jefferis, S. A. (2016). Performance of bored piles constructed using polymer fluids: lessons from European experience. J. Perform. Constr. Facil. 30, No. 2, 1-9.
Lam, C., Troughton, V., Jefferis, S. \& Suckling, T. (2010). Effect of support fluids on pile performance - a filed trial in east London. Ground Engng 43, No. 10, 28-31.

Lam, C., Jefferis, S. A. \& Martin, C. M. (2013). Effects of polymer and bentonite support fluids on concrete-sand interface shear strength. Géotechnique 64, No. 1, 28-39, http://dx.doi.org/ 10.1680/geot.13.P.012.

Lee, W., Lee, W., Lee, S. \& Salgado, R. (2004). Measurement of pile load transfer using the fiber Bragg grating sensor system. Can. Geotech. J. 41, No. 6, 1222-1232.

Lehane, B. M. \& Jardine, R. J. (1994). Displacement-pile behaviour in a soft marine clay. Can. Geotech. J. 31, No. 2 , 181-191.

Lehane, B. M., Jardine, R. J., Bond, A. J. \& Frank, R. (1993) Mechanisms of shaft friction in sand from instrumented pile tests. J. Geotech. Engng 119, No. 1, 19-35.

Liu, J. \& Zhang, M. (2012). Measurement of residual force locked in open-ended pipe pile using FBG-based sensors. Electron. J. Geotech. Engng 17, 2145-2154.

McCabe, B. A. \& Lehane, B. M. (2006). Behavior of axially loaded pile groups driven in clayey silt. J. Geotech. Geoenviron. Engng 132, No. 3, 401-410.

McNamara, A. M., Suckling, T. P., McKinley, B. \& Stallebrass, S. E. (2014). A field trial of a reusable hollow cast-in-situ pile. Proc. Instn Civil Engrs - Geotech. Engng 167, No. 4, 390-401, http://dx.doi.org/10.1680/geng.12.00102.

Mohamad, H., Soga, K., Pellew, A. \& Bennett, P. J. (2011) Performance monitoring of a secant-piled wall using distributed fiber optic strain sensing. J. Geotech. Geoenviron. Engng ASCE 137, No. 12, 1236-1243.

Nicholson, D. P., Chapman, T. J. P. \& Morrison, P. (2002) Pressuremeter proves its worth in London's Docklands. Ground Engng 35, No. 3, 32-34.

Ouyang, Y., Broadbent, K., Bell, A., Pelecanos, L. \& Soga, K. (2015). The use of fibre optic instrumentation to monitor the O-Cell load test on a single working pile in London. Proceeding of the XVI European conference on soil mechanics and geotechnical engineering ICE, Edinburgh, UK, Thomas Telford, Edinburgh, pp. 643-648.

Randolph, M. F. (2003). Science and empiricism in pile foundation design. Géotechnique 53, No. 10, 847-875, http://dx.doi.org/ 10.1680/geot.2003.53.10.847.

Schwamb, T. \& Soga, K. (2015). Numerical modelling of a deep circular excavation at Abbey Mills in London. Géotechnique 65, No. 7, 604-619, http://dx.doi.org/10.1680/ geot.14.P.251

Seo, H., Prezzi, M. \& Salgado, R. (2013). Instrumented static load test on rock-socketed micropile. J. Geotech. Geoenviron. Engng 139, No. 12, 2037-2047.

Soga, K. (2014). XII Croce Lecture: understanding the real performance of geotechnical structures using an innovative fibre optic distributed strain measurement technology. Riv. Ital. Geotech. 4, 7-48.

Soga, K., Kwan, V., Pelecanos, L., Rui, Y., Schwamb, T., Seo, H. \& Wilcock, M. (2015). The role of distributed sensing in understanding the engineering performance of geotechnical structures. Proceedings of the XVI European conference on soil mechanics and geotechnical engineering, Edinburgh, UK, Thomas Telford, Edinburgh, pp. 13-48.

Yang, Z. X., Jardine, R. J., Zhu, B. T. \& Rimoy, S. (2014). Stresses developed around displacement piles penetration in sand. J. Geotech. Geoenviron. Engng 140, No. 3, 1-13. 